\title{
Ice-Streaming in the Southern Champlain and Northern Hudson River Valleys, Vermont and New York
}

\author{
Stephen Wright \\ Department of Geology, University of Vermont \\ Crevassed margin of the Bindschadler lce Stream, Antarctica \\ Photo by N. Nereson, NASA Earth Observatory
}




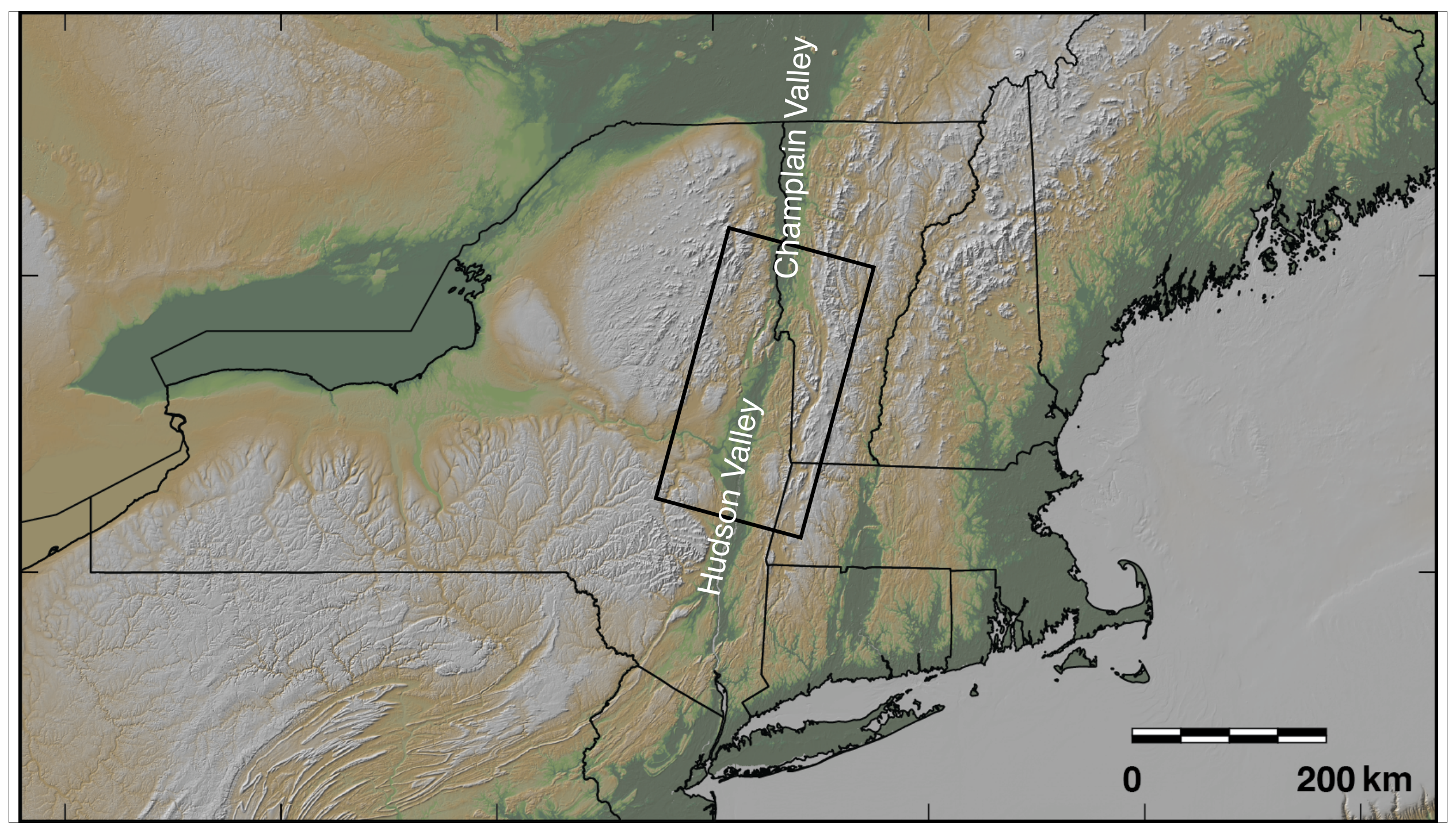




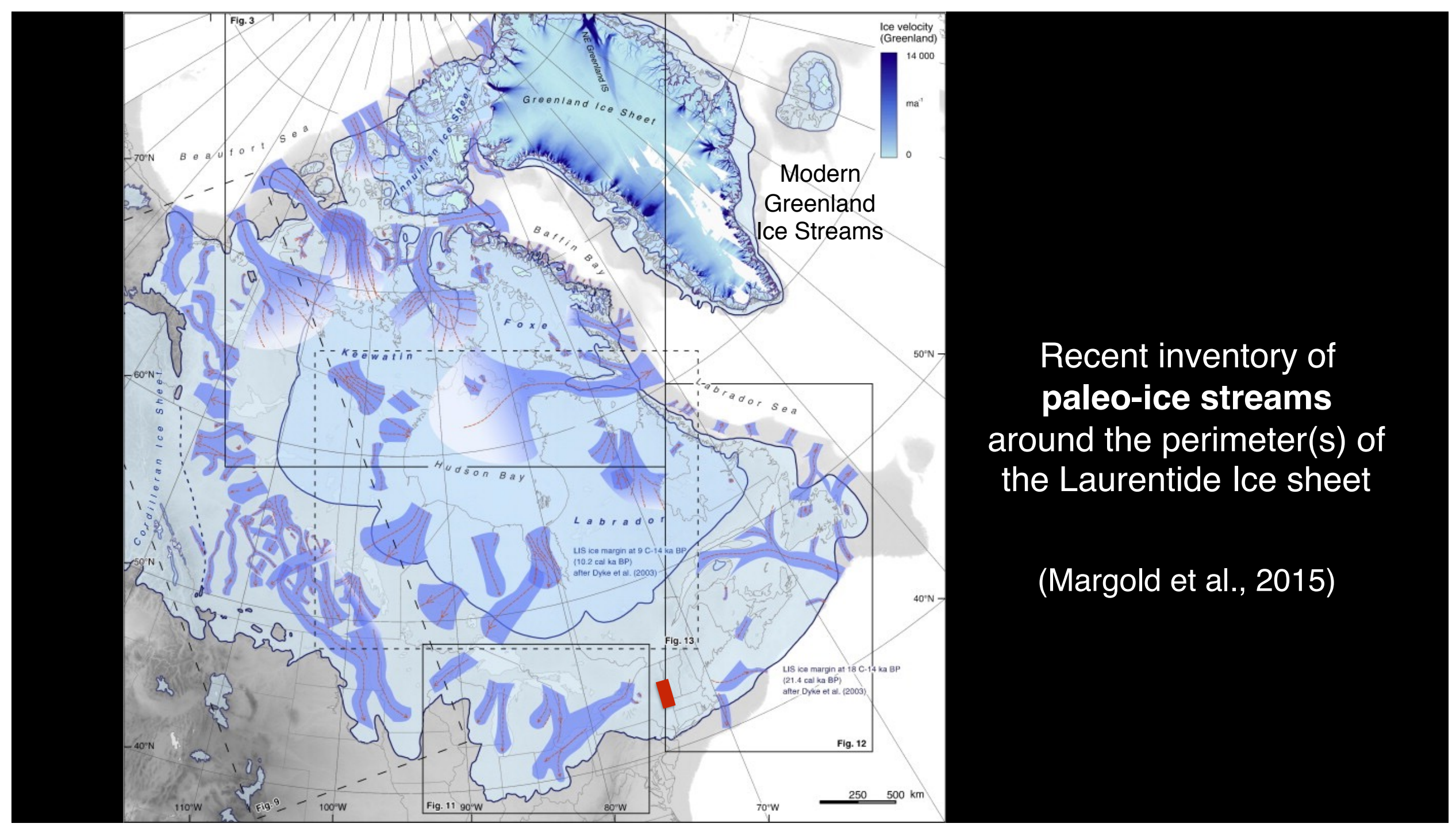




\section{How have these paleo-ice streams been identified?}

1. Characteristic Shape and Dimensions

Convergent ice flow from the surrounding ice sheet into the ice stream.

2. Topographic Ice Streams located in large-scale troughs

3. Underlain by "Soft Beds:" Low-strength rocks/surficial materials

4. Highly elongate, streamlined bed-forms: Mega-scale glacial lineations 


\section{(1) Characteristic Shape and Dimensions}

- Convergent flow lines in the onset zone feeding the ice stream.

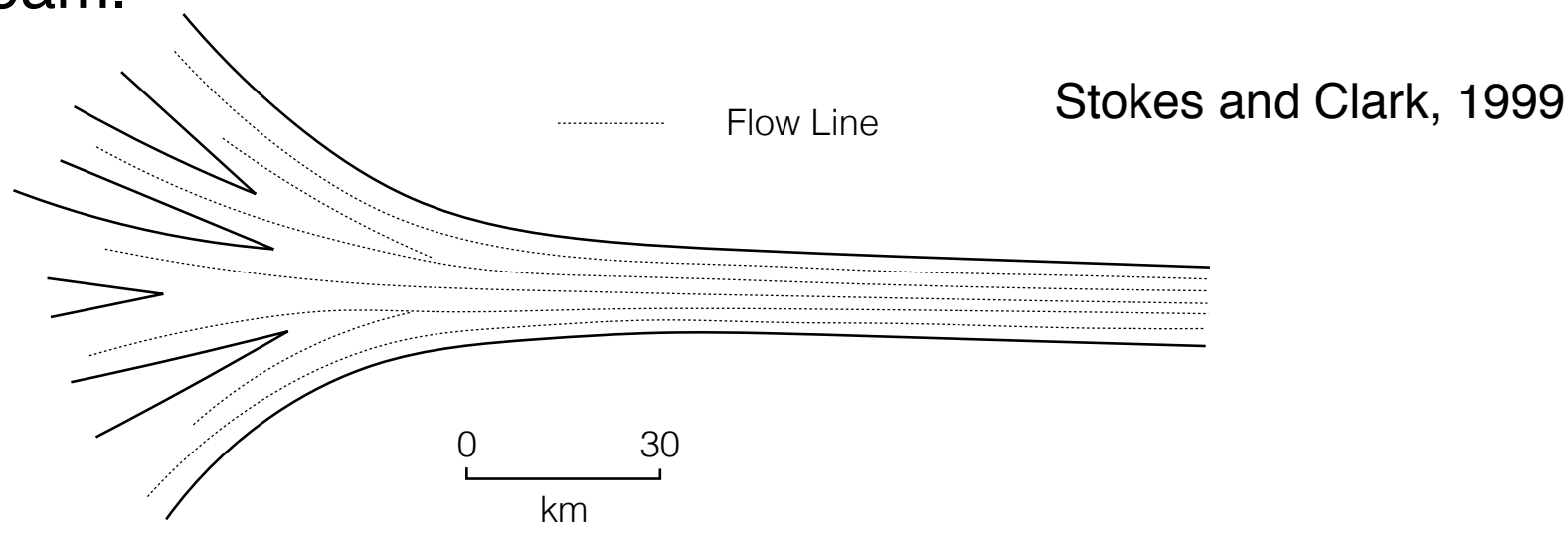

- Dimensions are generally $>20 \mathrm{~km}$ width, $>150 \mathrm{~km}$ length. 


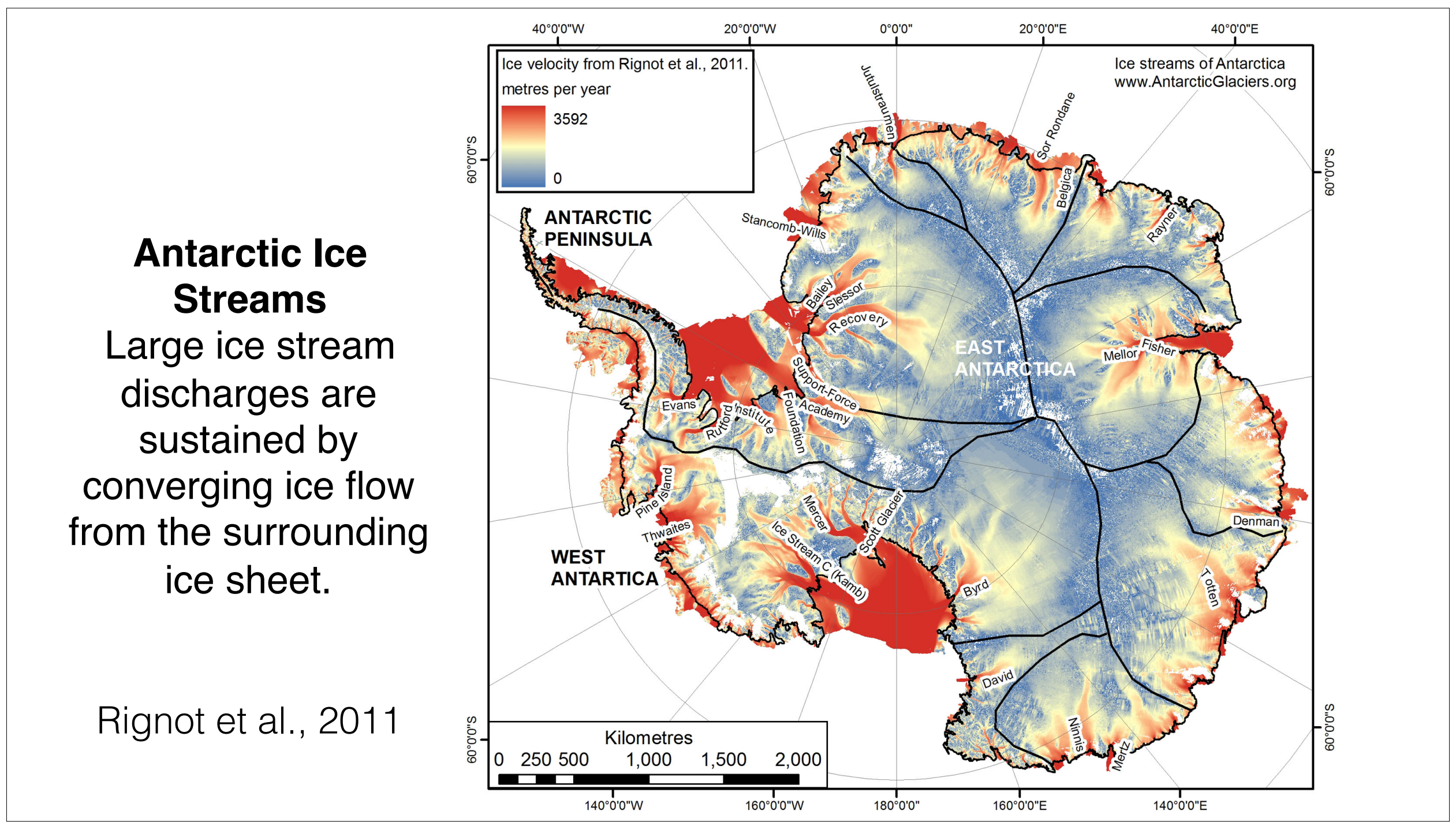


Convergent ice flow into paleo-ice streams, northern Laurentide Ice Sheet

(Margold et al., 2015)

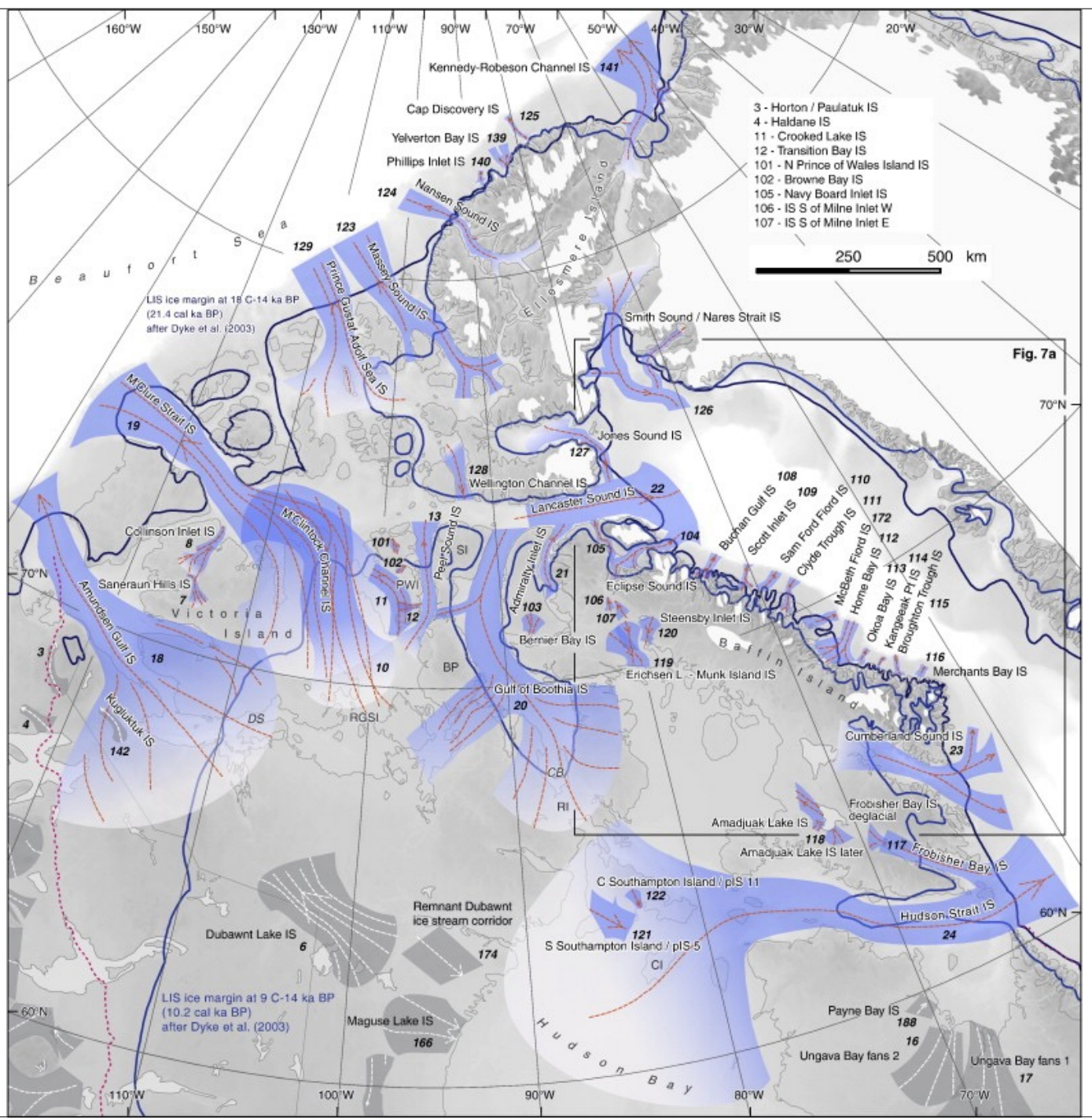




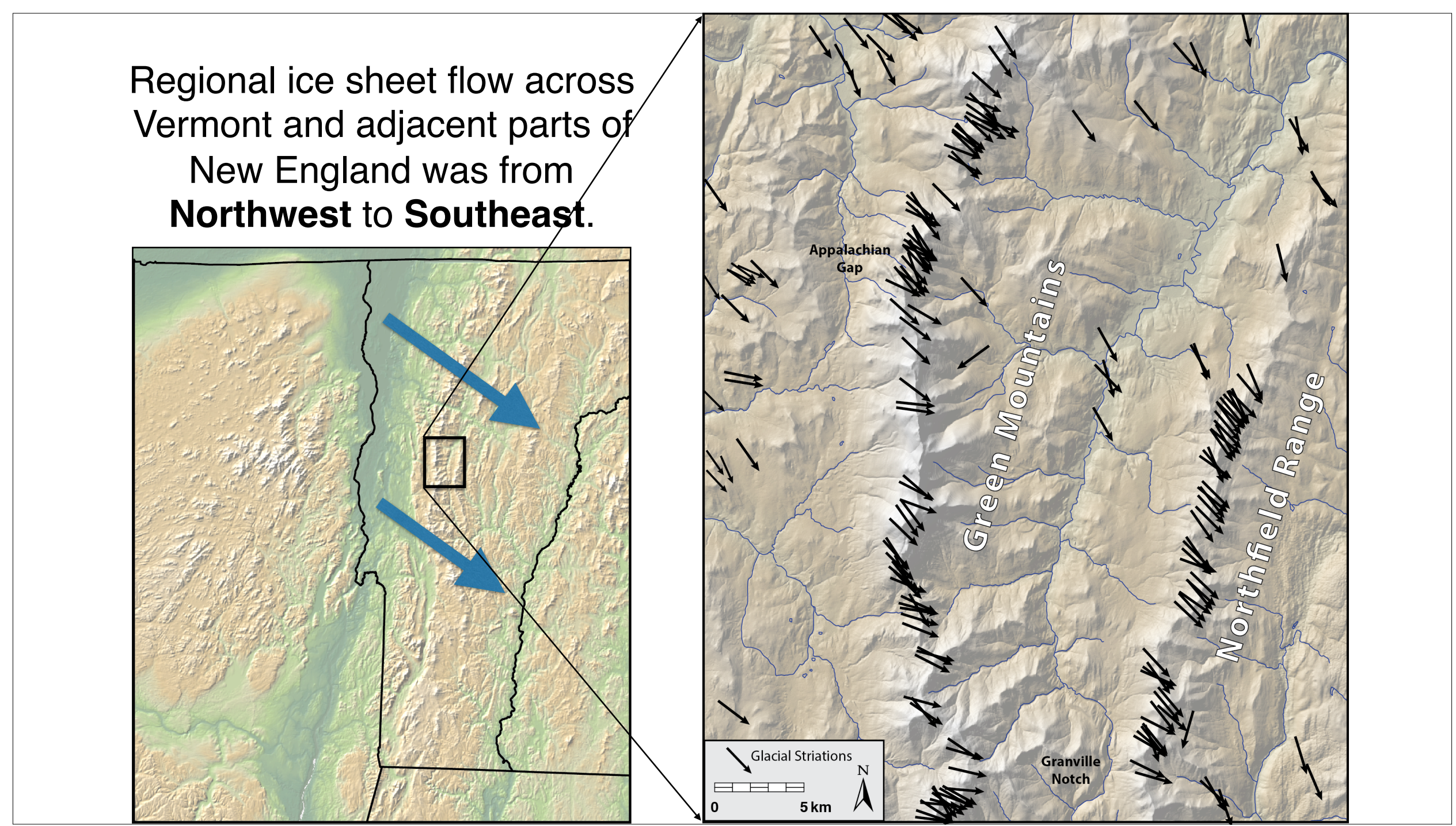




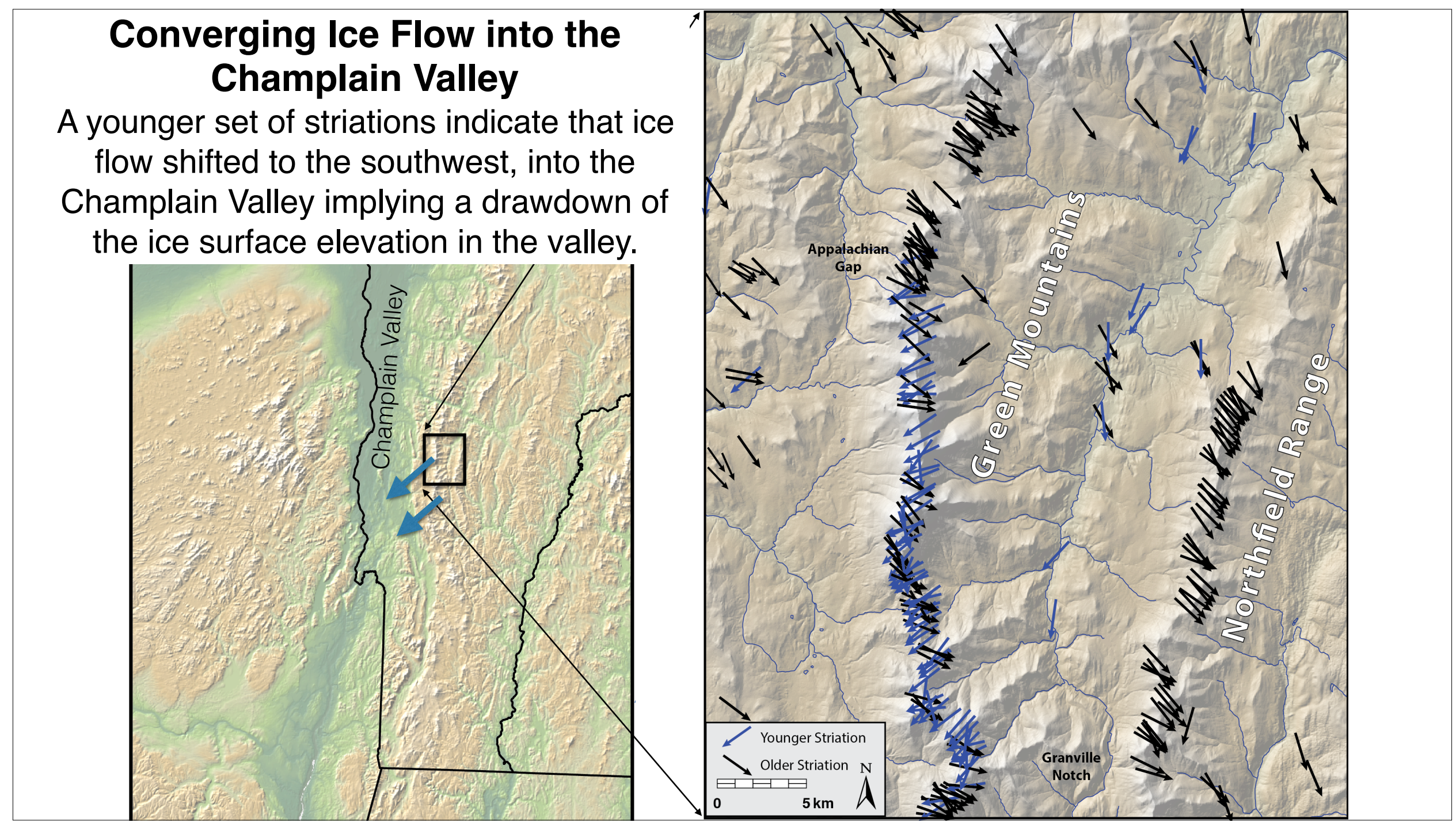




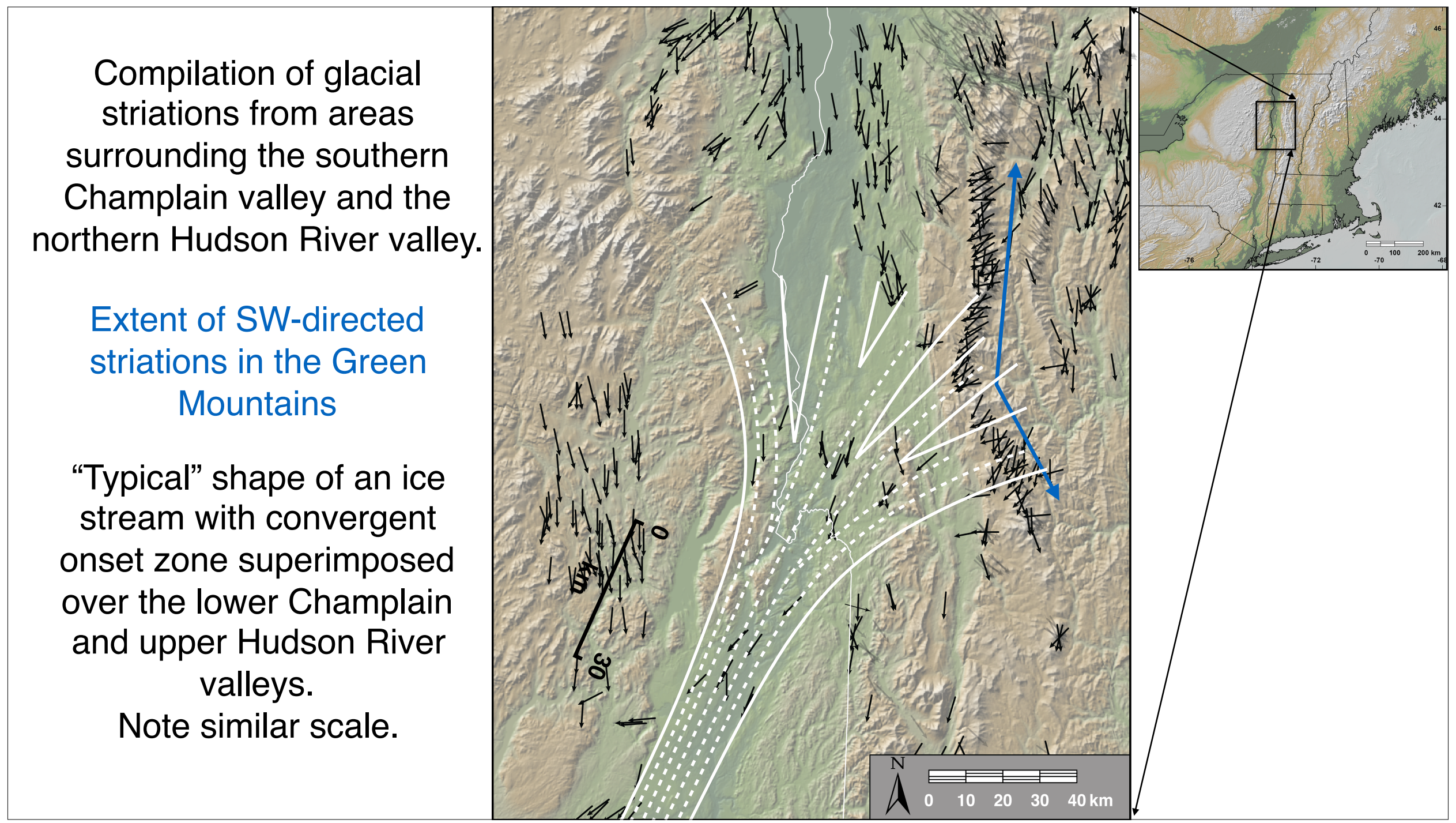




\section{(2) Bedrock Troughs}

Topographic ice streams are localized in substantial bedrock troughs.

Morlighem et al., 2014
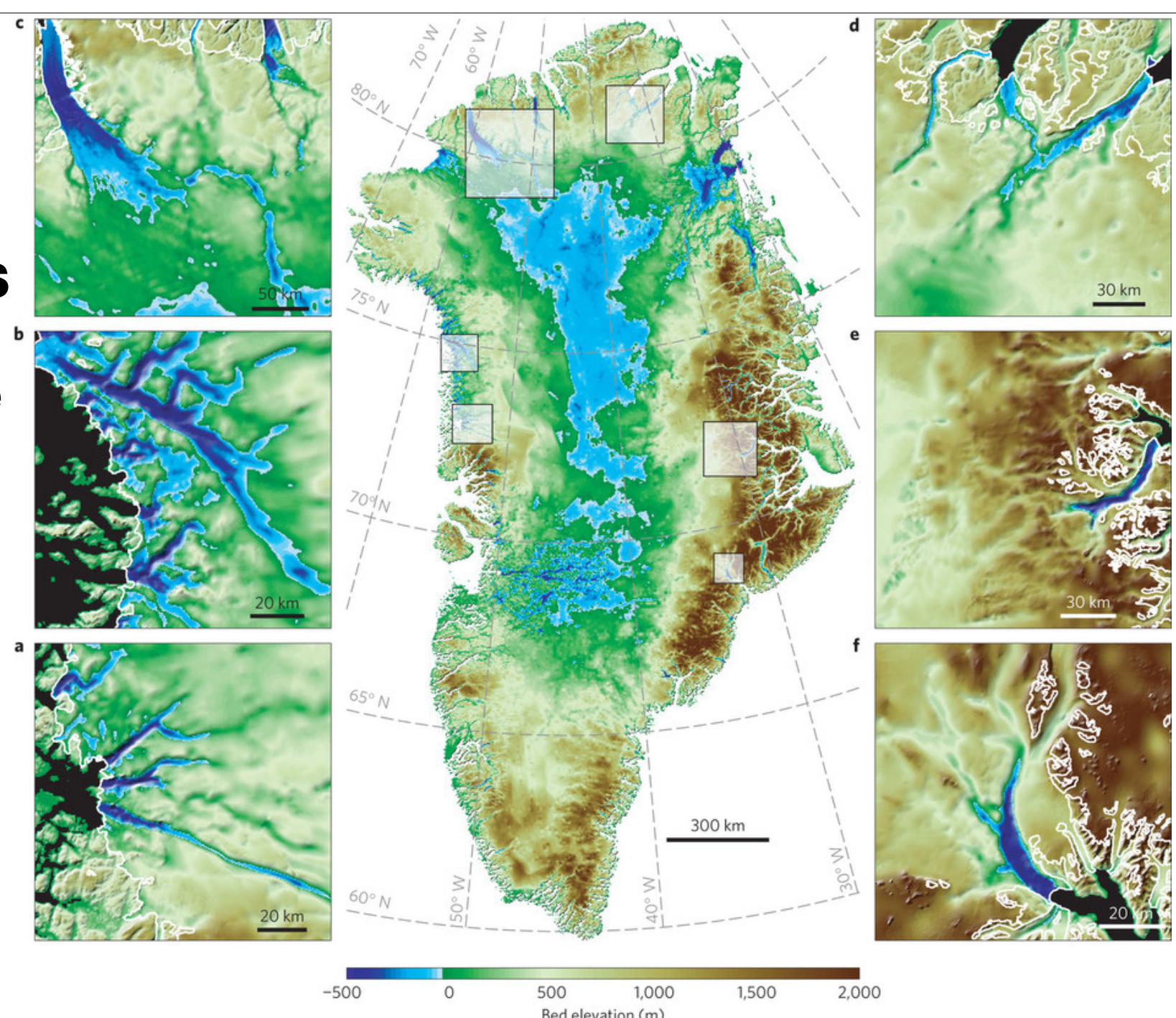
The Hudson/

Champlain Valley is the only through-going bedrock trough across the New York/New England mountains.

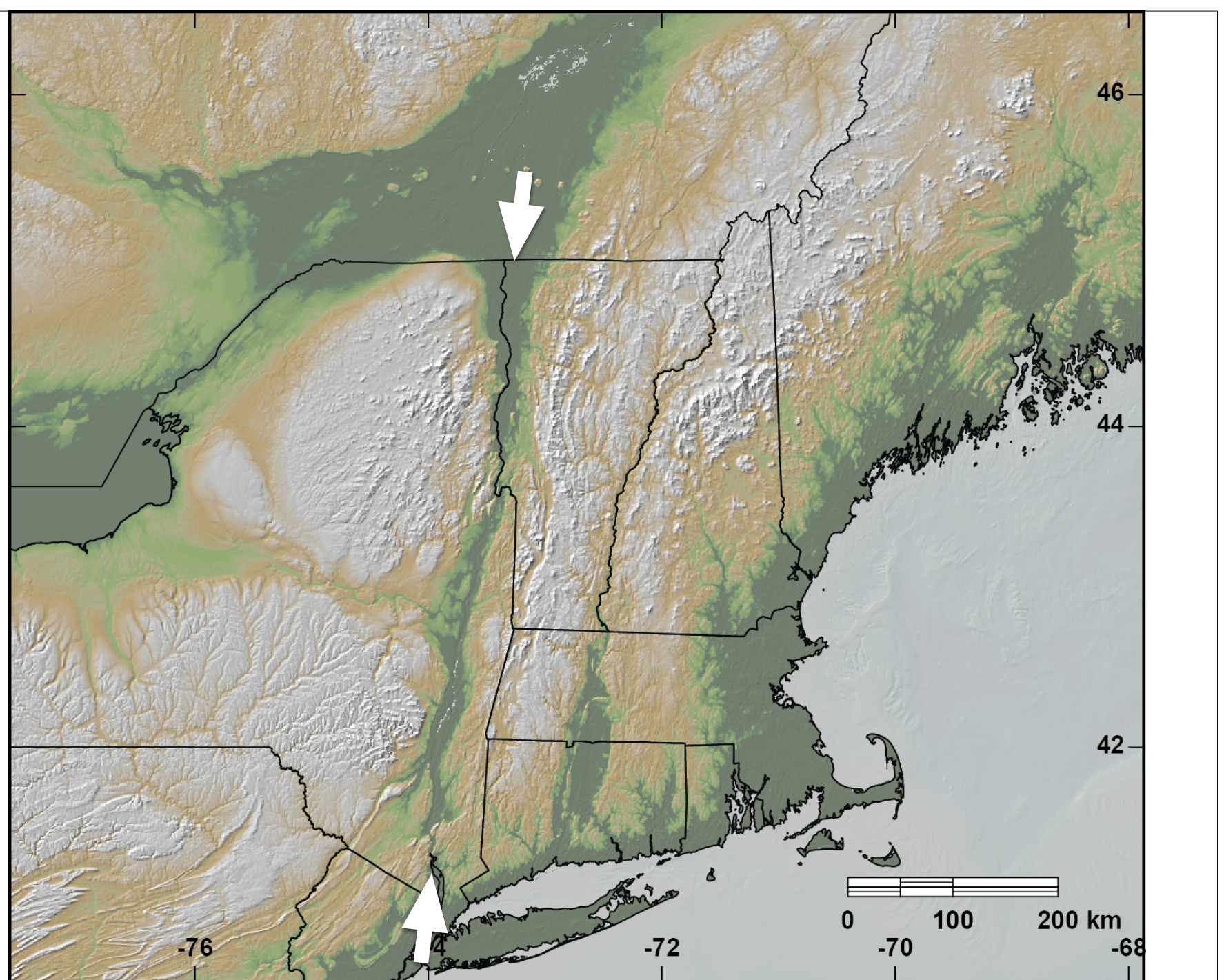




\section{(3) "Soft Beds"}

Ice Streams are commonly underlain by weak clay/calcite-rich rocks that source weak tills.

Paleo-ice streams in the western interior (shown in blue) preferentially developed on "soft" sedimentary vs "hard" Canadian shield rocks.

Margold et al., 2015

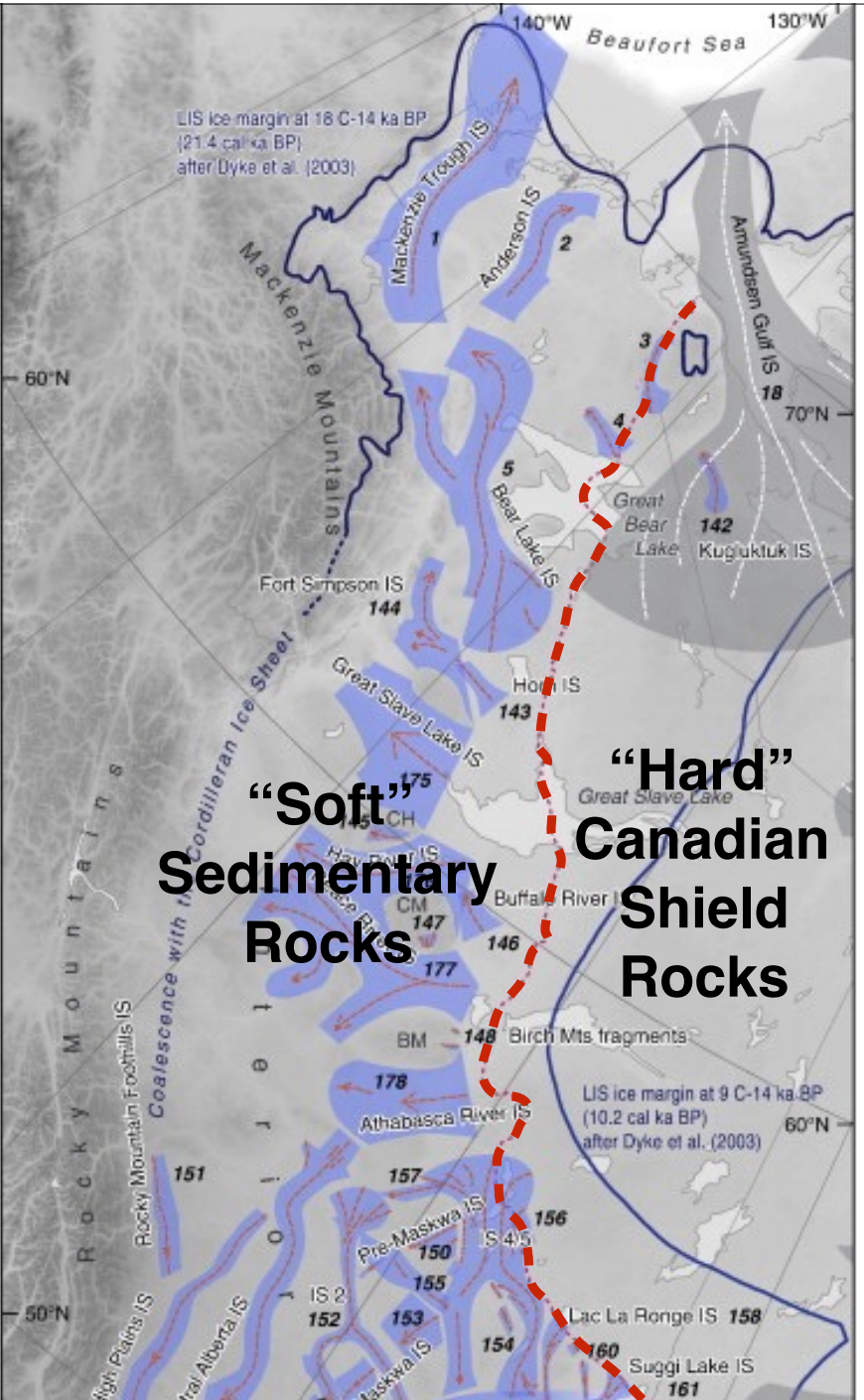




\section{"Soft Beds"}

The Champlain and Hudson River valleys are bordered by metamorphic rocks, but are underlain by weak sedimentary rocks largely composed of carbonate and clay minerals.

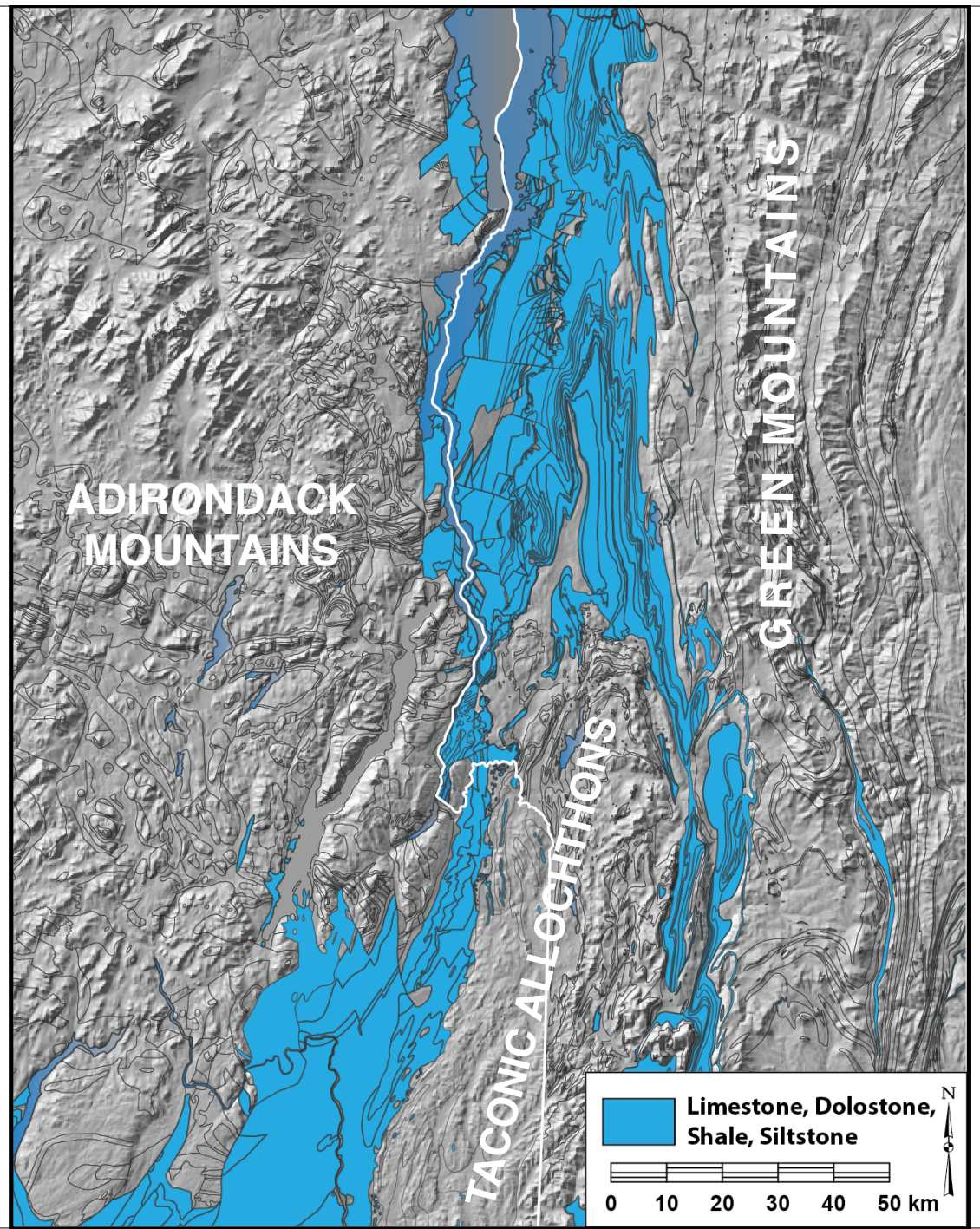




\section{"Soft Beds"}

- At the end of the previous glacial period the Champlain and Hudson valleys were likely occupied by glacial lakes, Paleo-Glacial Lakes Albany and Vermont.

- Similar to today, these valleys were mantled with lacustrine sediments largely derived from the underlying limestones, dolostone, siltstones, and shales.

- These weak, fine-grained lacustrine sediments were incorporated into the till.

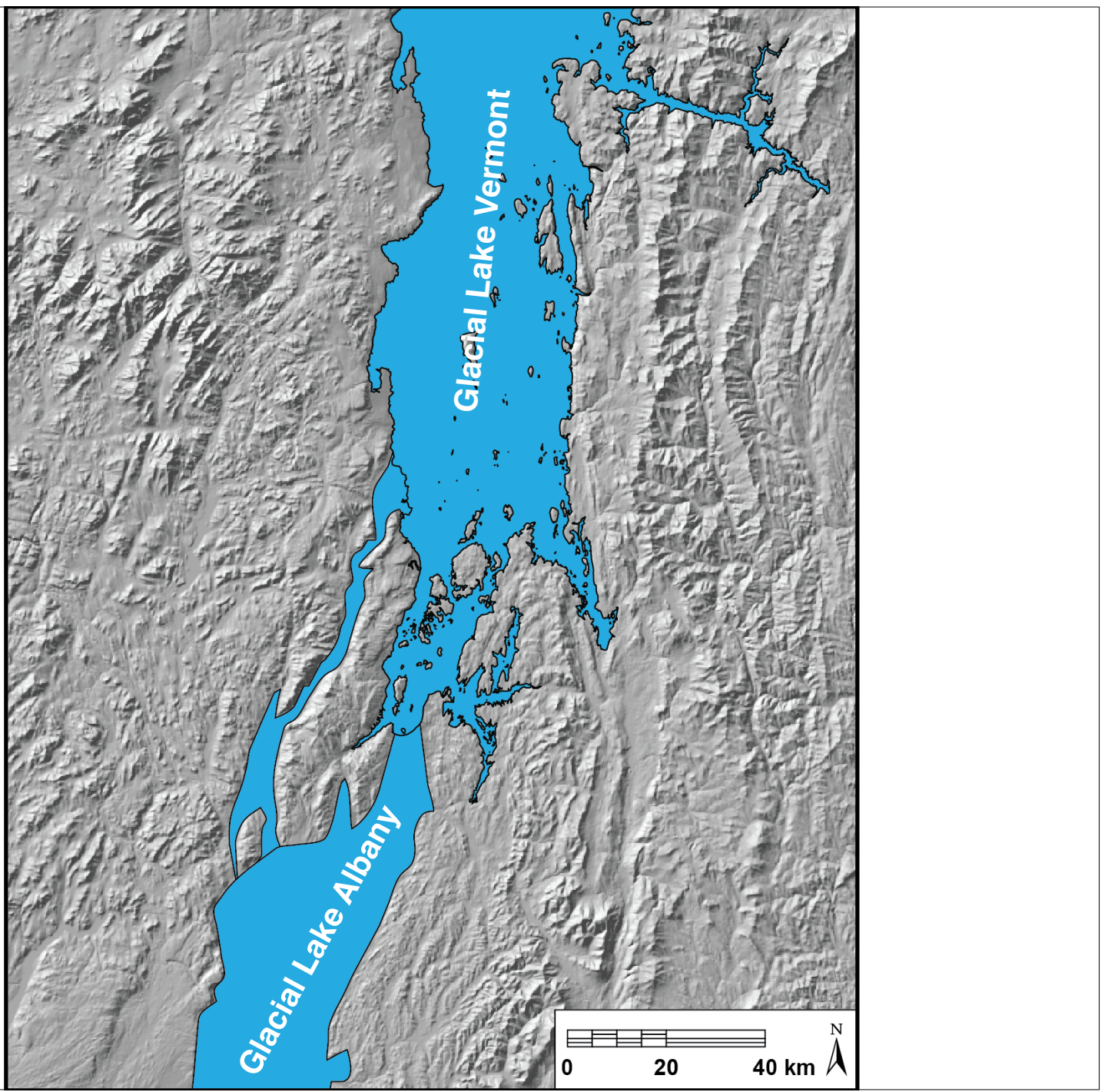




\section{(4) Streamlined Bed-forms}

- "Mega-scale glacial lineations"

- Drumlins, flutes, etc. with Length/Width Ratios > 10:1

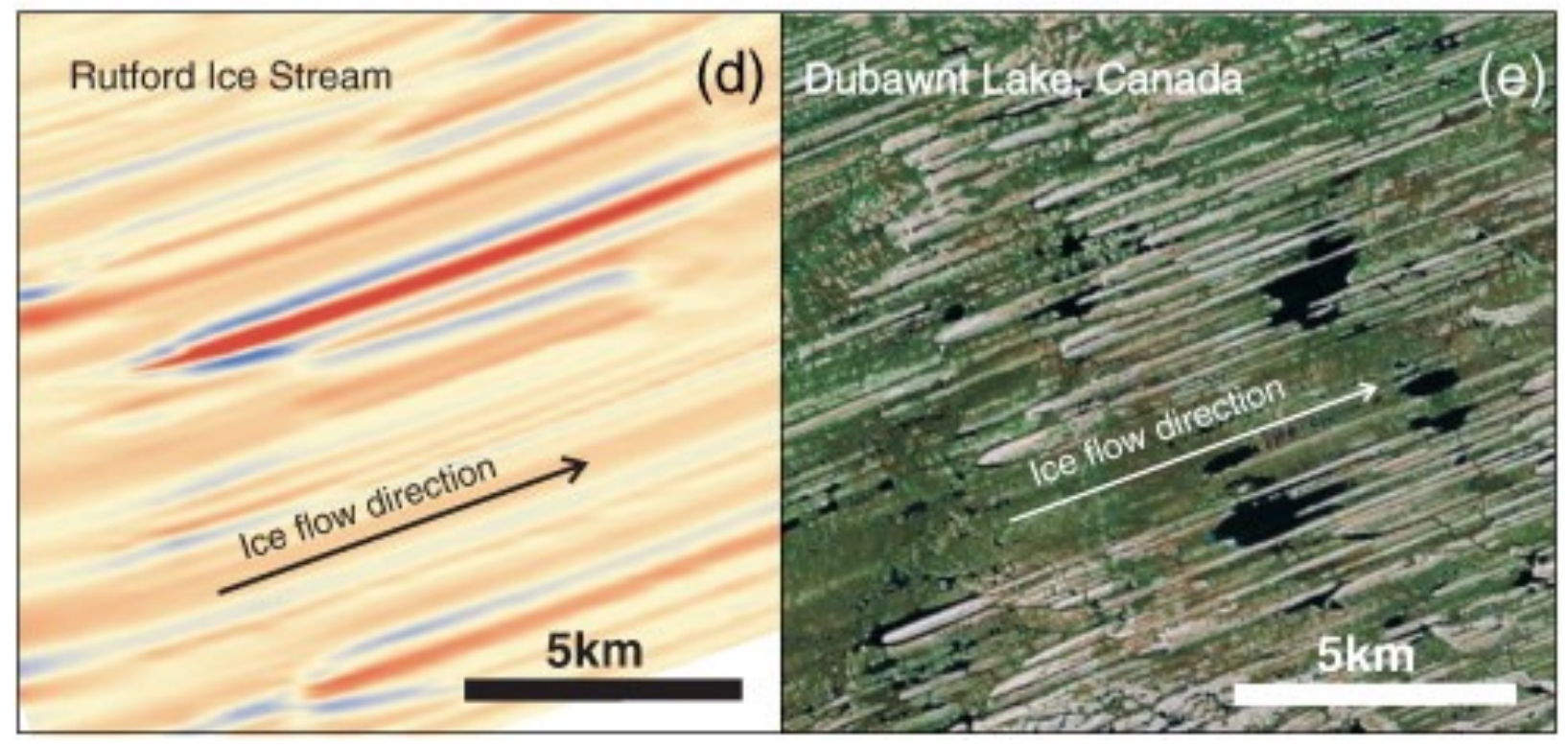

Marigold et al., 2015 


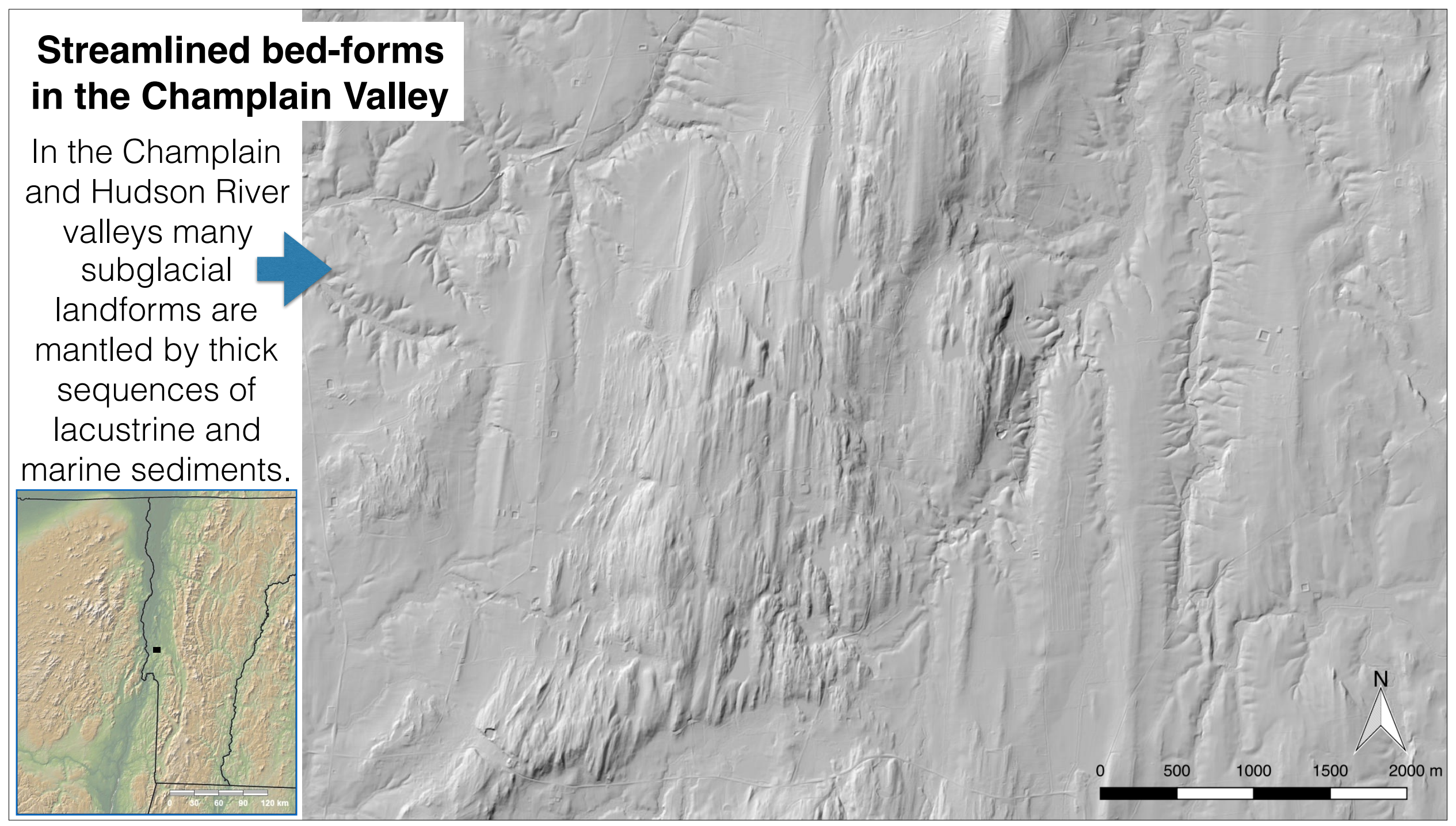




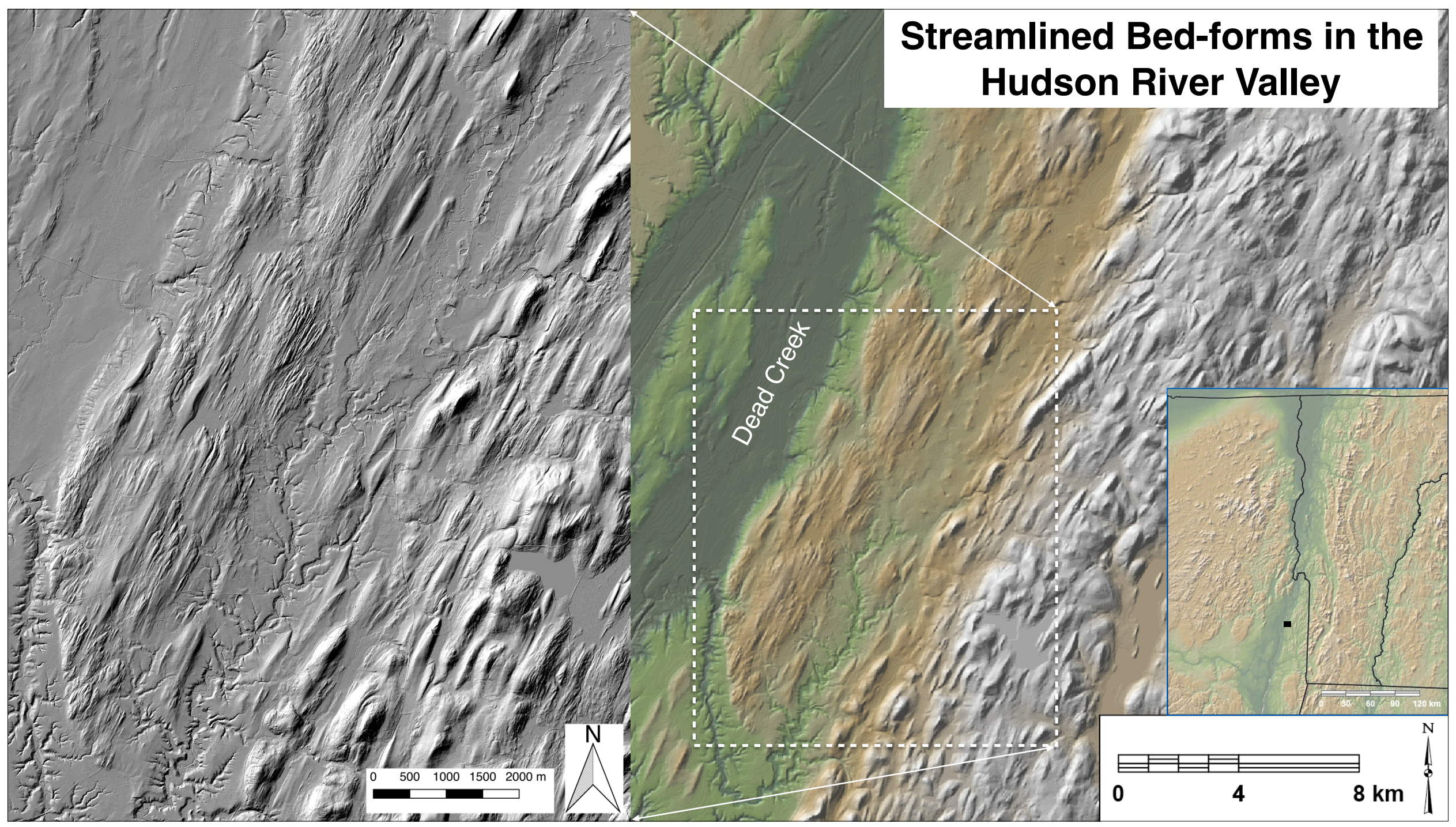




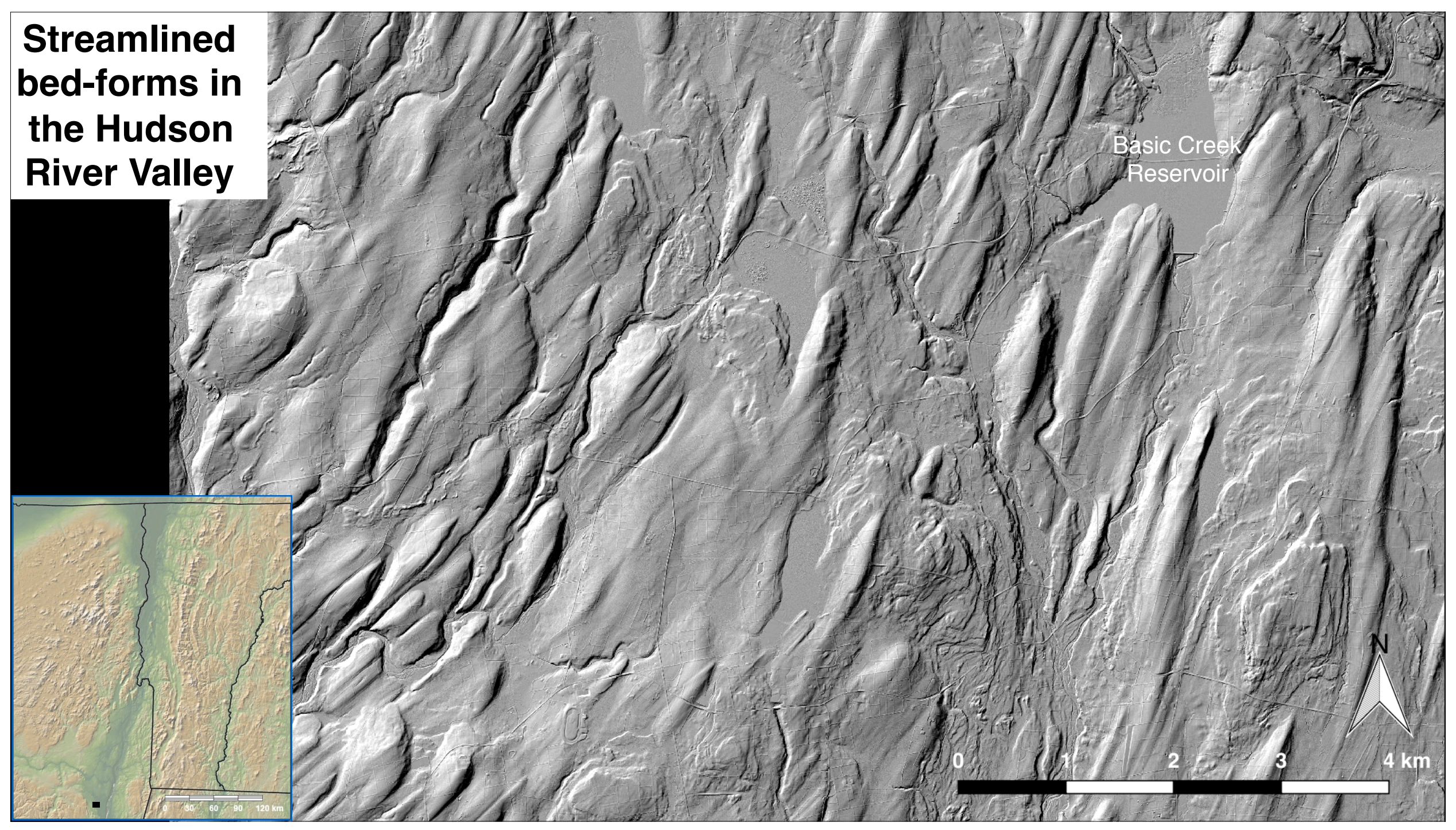




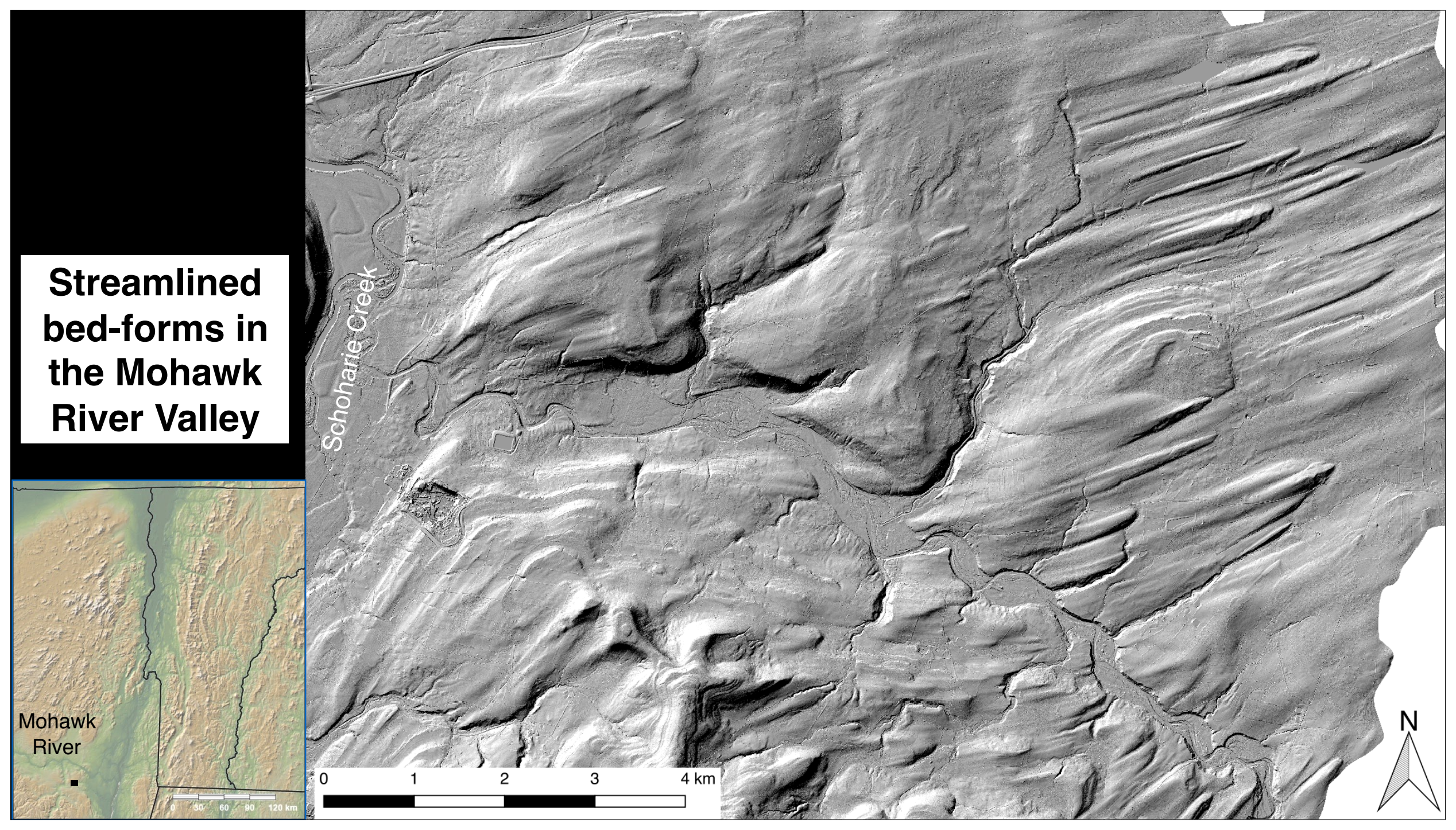




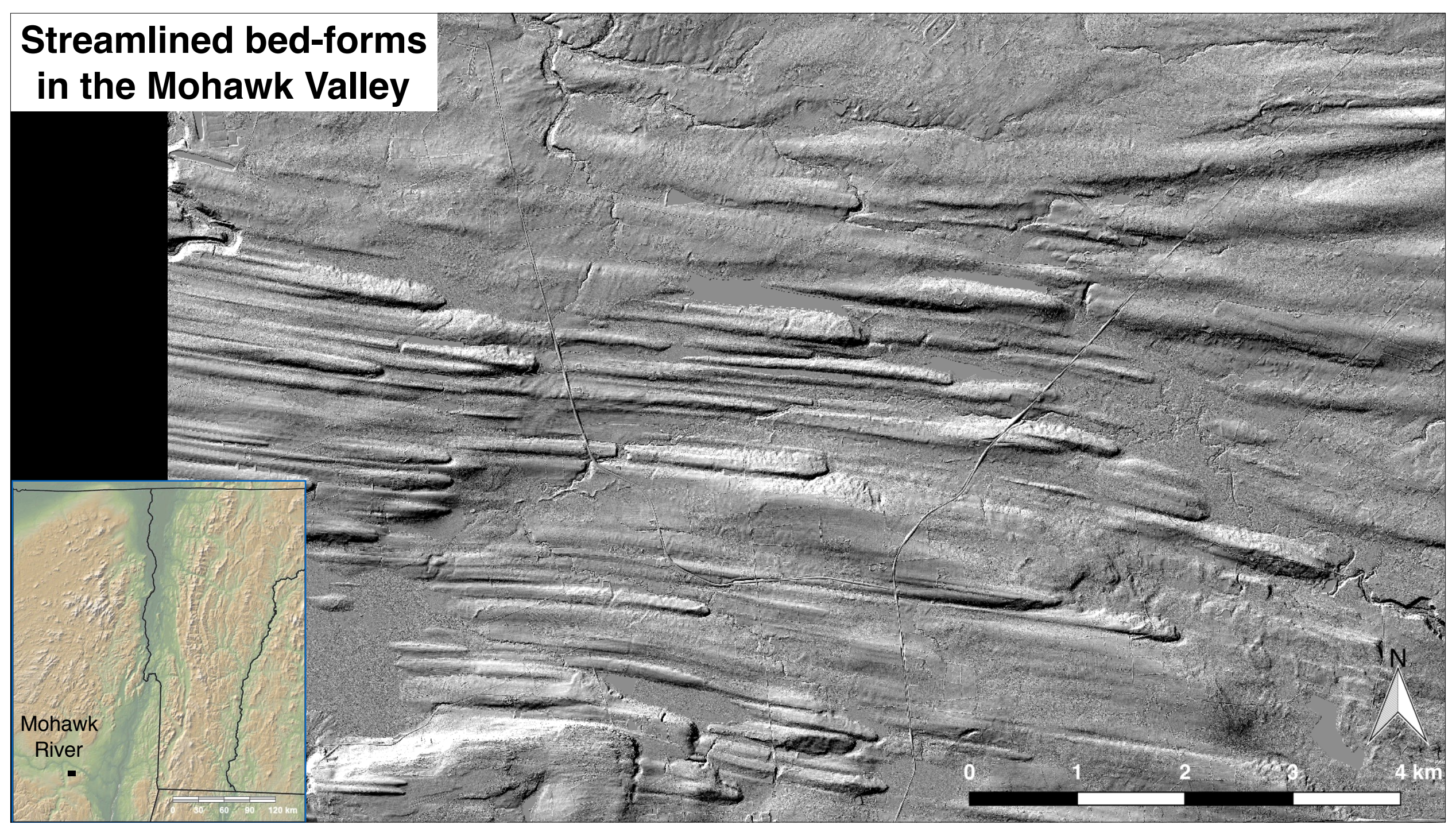




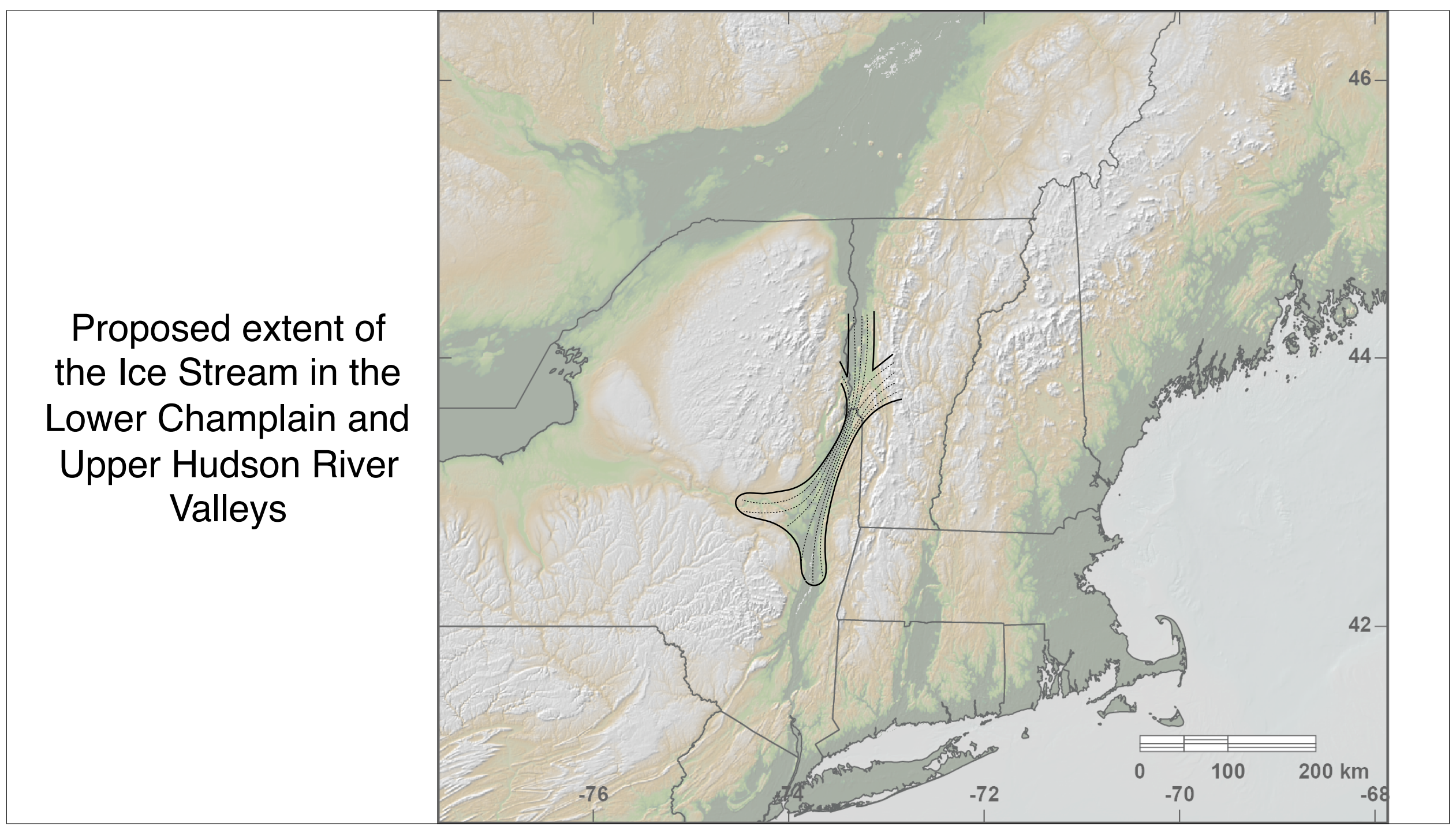




\section{Ephemeral Ice Stream}

- "Ephemeral" implies that this postulated ice stream was relatively short-lived, only active for 10's to several 100's of years.

- Extent of SW-directed striations across the Green Mountains is limited.

- SW-directed striations aren't overprinted by any younger striations implying that this part of the Green Mountain range emerged from the ice shortly after SW-flow ceased.

- This period of fast ice flow occurred while the ice sheet was retreating.

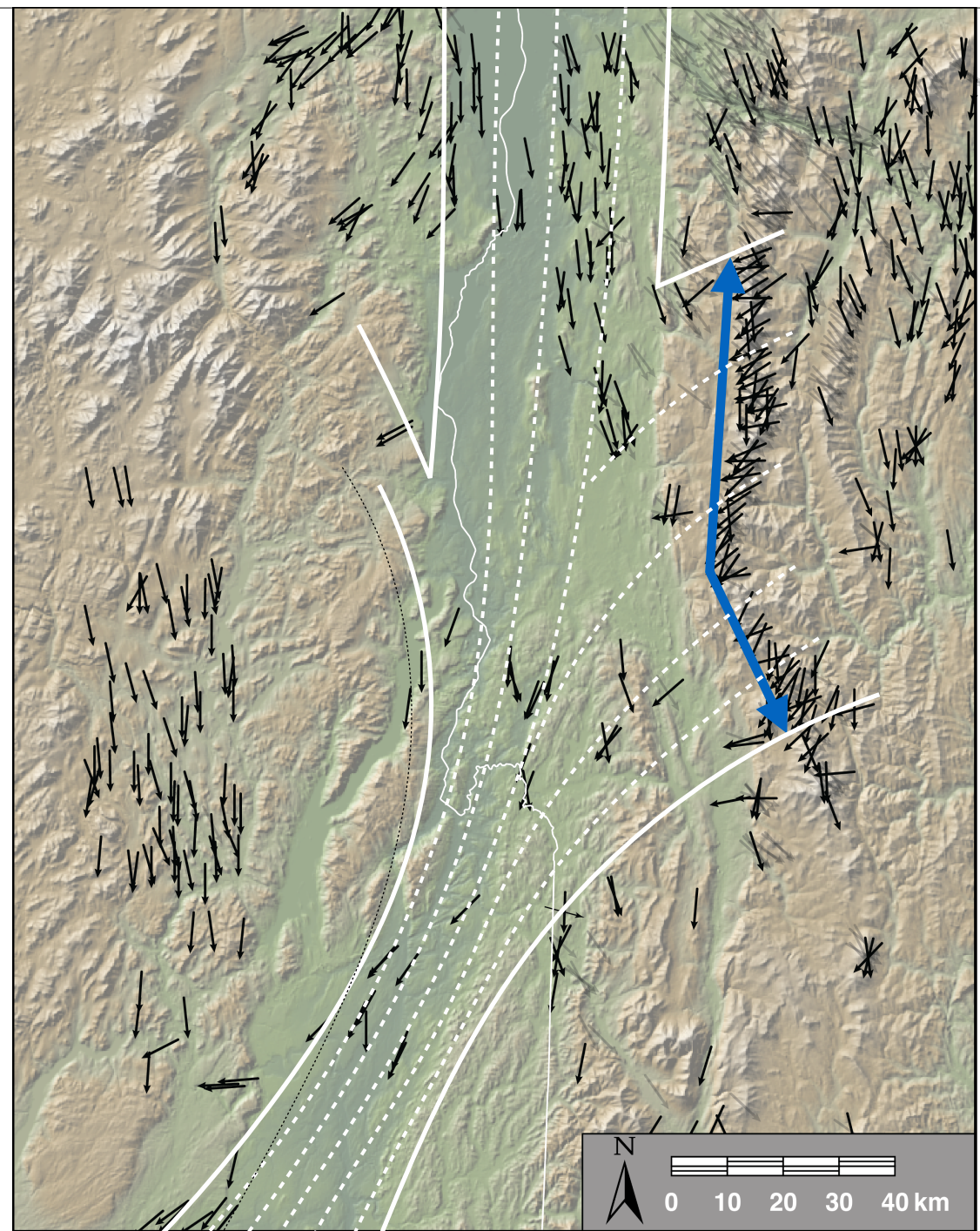




\section{Conclusions}

An Ephemeral Ice Stream in the Champlain/Hudson River Valleys supported by:

- Converging ice flow indicated by striations

- Characteristic shape and dimensions of modern ice streams

- Location in a major topographic trough across the mountains

- Shale, Limestone, Dolostone, and Lacustrine sediments underlying these valleys are the source materials for weak basal tills.

- Streamlined bed-forms
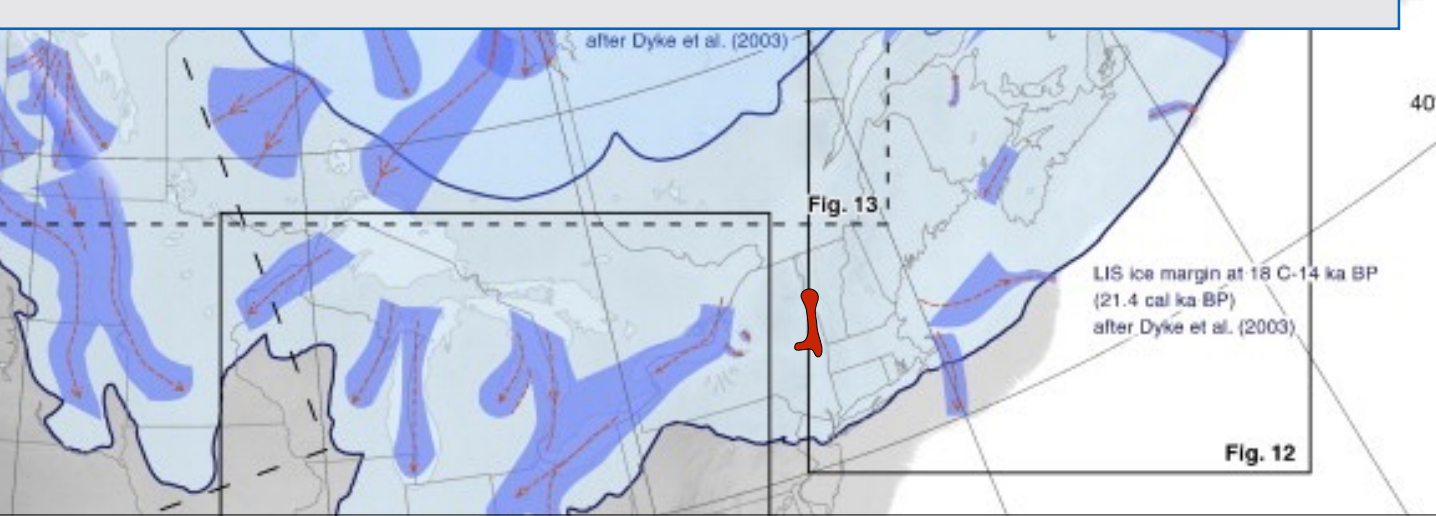